\title{
Recommendations of RAAS Blockers Use Amidst the Coronavirus Pandemic
}

\author{
Joshua Henrina', Iwan Cahyo Santosa Putra', Hoo Felicia Hadi Gunawan', \\ Irvan Cahyadi', Leonardo Paskah Suciadi²
}

I Research Assistant, Siloam Heart Institute/ Siloam Hospitals Kebon Jeruk

2 Cardiologist, Siloam Heart Institute/ Siloam Hospitals

Kebon Jeruk

\section{Correspondence:}

Leonardo Paskah Suciadi,

Cardiologist

Heart Institute/ Siloam Hospitals

Kebon Jeruk.

Barat, Daerah Khusus Ibukota

Jakarta II 530

Telp.: +62821126590192

E-mail: Be.bakerstreet@gmail. com

\begin{abstract}
Currently, there are gaps in the knowledge regarding the safety of angiotensinconverting enzyme (ACE) inhibitors or angiotensin receptor blockers (ARBs) for COVID- 19 patients due to concern of ACE2, which is critical for viral entry and their levels are upregulated when using these renin-angiotensin-aldosterone system blockers. ACE2, a glycoprotein metalloprotease that is ubiquitously found in human organs, played an essential role in physiologic and pathological states. Despite sharing homology, ACE2 is different from ACE, and while the latter cleaves angiotensin I to angiotensin 2, the former cleaves angiotensin 2 to angiotensin I-7. Extrapolated from experimental animal studies, ACE2 and angiotensin I-7 are important and protective for the lung physiology based on mice model of acute lung injury by various causes. Other evidence also demonstrates harm over benefits when ceasing RAAS blockers, particularly in patients with pre-existed cardiovascular disease, in which these drugs are proven to be life-saving. In paucity of evidence derived from well-designed study, majority of societies have recommended to continue RAAS blockers until new evidence says otherwise.
\end{abstract}

(Indonesian J Cardiol. 2020;41:98-105)

Keyword: SARS-Cov-2, COVID-19, ACEi, ARB, ACE2

\section{Introduction}

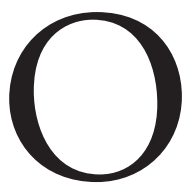

n 31st December 2019, the health authorities in China notified the World Health Organization (WHO) of an outbreak of pneumonia of unknown causes in Wuhan, Hubei Provinces, China. ${ }^{1}$ A new type of coronavirus is responsible for this viral respiratory disease initially called as a novel coronavirus (nCov) but now identified as severe acute respiratory syndrome coronavirus -2 (SARS-CoV2). ${ }^{2}$ This virus is responsible for SARS-like disease called coronavirus disease 2019 (COVID-19). Since then, WHO has declared it a public health emergency of international concern and raised its status as a pandemic. ${ }^{3}$ As of 13th April 2020, SARS$\mathrm{CoV} 2$ has spread to more than 210 countries/areas/ 
territories with total global cases of nearly 1.7 million cases, and the overall mortality has surpassed 100.000 deaths. ${ }^{4,5}$

Currently, there are gaps in the knowledge regarding the safety of angiotensin-converting enzyme (ACE) inhibitors or angiotensin receptor blockers (ARBs) for COVID-19 patients that are medically indicated. Controversies whether to continue or discontinue $\mathrm{ACEi} / \mathrm{ARB}$ s usage exist because the main pathway of viral entry into pneumocyte, mainly the type 2 , is via ACE2, which their levels are upregulated when using these RAAS blockers. ${ }^{6,7}$

Furthermore, both drugs are widely used for various indications, particularly in cardiovascular diseases. ${ }^{8,9}$ Therefore, guidance on the use of these drugs in COVID-19 patients is sorely needed. In this review, we explain the interaction of SARS-CoV2 and ACE, the benefit of continuing vs. harm of discontinuing of RAAS blockers, and we presented summaries of recommendations from various societies and colleges around the world regarding the use of $\mathrm{ACEi} / \mathrm{ARB}$ in COVID-19 patients.

\section{SARS-CoV2 and Angiotensin Converting En- zyme (ACE)}

Coronaviruses are positive-stranded RNA viruses with a crown-like appearance under an electron microscope. Among the structural elements, there are spike glycoproteins composed of two subunits ( $\mathrm{S} 1$ and S2). ${ }^{10}$ Cell entry of SARS-CoV-2 requires the binding of $\mathrm{S} 1$ glycoprotein to ACE2 and the serine protease TMPRSS2 for $S$ protein priming. ${ }^{11}$ ACE 2 is expressed in many organs, including intestine, endothelium, heart, kidney, and lung as well, specifically in type 2 pneumocytes and macrophages. ${ }^{12,13}$ ACE2 shares considerable homology to ACE, but unlike ACE, it does not convert angiotensin I (Ang I) to angiotensin II (Ang II). ACE2 degrades angiotensin I to angiotensin-(1-9) and angiotensin II to angiotensin-(1-7). ${ }^{12,14}$

The renin-angiotensin-aldosterone system (RAAS) is a critical regulator of blood volume and systemic vascular resistance. RAAS is responsible for more chronic alterations while baroreceptor reflex responds in the short-term to decreased arterial pressure. ${ }^{15}$ The modern concept of the RAS includes renin, angiotensinconverting enzyme $[\mathrm{ACE}]$, angiotensin I, angiotensin II, and angiotensin type 1 and type 2 receptors, novel enzymes, peptides, and receptors (ACE2,3,4 Ang-(1-7), pro-renin receptor, and Mas). ${ }^{16}$

ACE2 degrades angiotensin I to angiotensin-(1-9) and angiotensin II to angiotensin-(1-7). Actions of angiotensin-(1-7) are not restricted to the cardiovascular system as it also affects other systems such as renal hemodynamic, inflammation, and fibrosis. ${ }^{16}$ While renin, angiotensin II, and aldosterone renin, angiotensin II, and aldosterone act to elevate arterial pressure in response to decreased renal blood pressure, reduced salt delivery to the distal convoluted tubule, and/or betaagonism, ACE2 counterbalances the function of ACE and negatively regulates angiotensin II production. ${ }^{13,15}$ ACE2 deficiency causes augmentation in vascular inflammation, and inflammatory responses detrimental in cardiovascular diseases, and kidney disease, as well as enhances pulmonary, cardiac, and renal injuries. Expression of ACE2 preserves cardiac function, ventricular wall motion, and contractility, and protects from remodelling. ${ }^{17}$

ACE 2 is a glycoprotein metalloprotease that exists mostly as membrane-bound and with low blood solubility. ${ }^{18}$ The soluble level of ACE2 is often increased in pathological states due to membrane bound ACE2 shedding. In mice model injected with SARS-CoV, it was found that due to ACE2 being a critical negative regulatory factor for severity of lung edema and acute lung failure, SARS-CoV spike protein-mediated ACE2 downregulation contributes to the severity of lung pathologies. ${ }^{19}$ It was found that ACE2 is a crucial receptor for SARS-CoV-2 and increased angiotensin I and II levels are thought to upregulate ACE2 activity, which then attenuates lung failure. ${ }^{19}$

In 2006, a study regarding ACE2 as SARS-CoV entry suggested that inhibition of ACE2 might be capable of blocking SARS-CoV infection. ${ }^{18}$ Tseng et. al, in 2007 found that in transgenic mice expressing human ACE2, a functional receptor to the virus, there were high susceptibility towards SARS-CoV infection. ${ }^{20}$

Recently, it is known that COVID-19 has three phases of the disease. As stated earlier7, phase one (infection), constitutes SARS-CoV-2 binding to ACE2 to infect cells, which then initiates localized inflammation, endothelial activation, tissue damage, and disordered cytokine release. ${ }^{21}$ Furthermore, the fusion of membrane interrupts angiotensin II metabolism, causing an increase in angiotensin II and a decrease in angiotensin-(1-7), 
augmenting inflammation, endothelial activation, and leukocyte and platelet recruitment. ${ }^{21}$

Afterward, phase two (dysregulated inflammation) is commenced by activation of pulmonary endothelial then leads to ACE1 shedding phenomenon, where ACE1 is rapidly liberated from the cell membrane, producing an initial rapid rise in angiotensin II. This can induce a positive feedback loop enhancing local inflammation, coagulation, and capillary leak. ${ }^{21}$

The final phase (hypo-inflammation - endothelial dysfunction) is marked by the dissipation of transiently increased ACE1 leads to lower angiotensin II concentrations. Low systemic angiotensin II leads to vasodilation, worsened capillary leak, and impaired endothelial conductance and autoregulation. ${ }^{21}$

Low angiotensin II also upregulates ACE2, possibly increasing susceptibility to SARS-CoV-2 in remote tissue. ${ }^{21}$ Although ACE2 shares some homology with an angiotensin-converting enzyme (ACE), it is not inhibited by ACEi and ARBs. ${ }^{14}$ Theoretically, RAAS blockade might cause an increase in host susceptibility towards SARS-CoV-2. Despite the lack of evidence, there have been advocates for both the use and cessation of ACEIs, ARBs, or both during the treatment for COVID-19.13

\section{The Harm of Discontinuing ACE-i or ARB Ther- apy for Cardiovascular Indication in COVID - 19 patients.}

Angiotensin II, a neurohumoral agent, plays a pivotal role in heart failure, primarily in ventricular remodeling (ventricular hypertrophy and dilatation). Both ACE-I

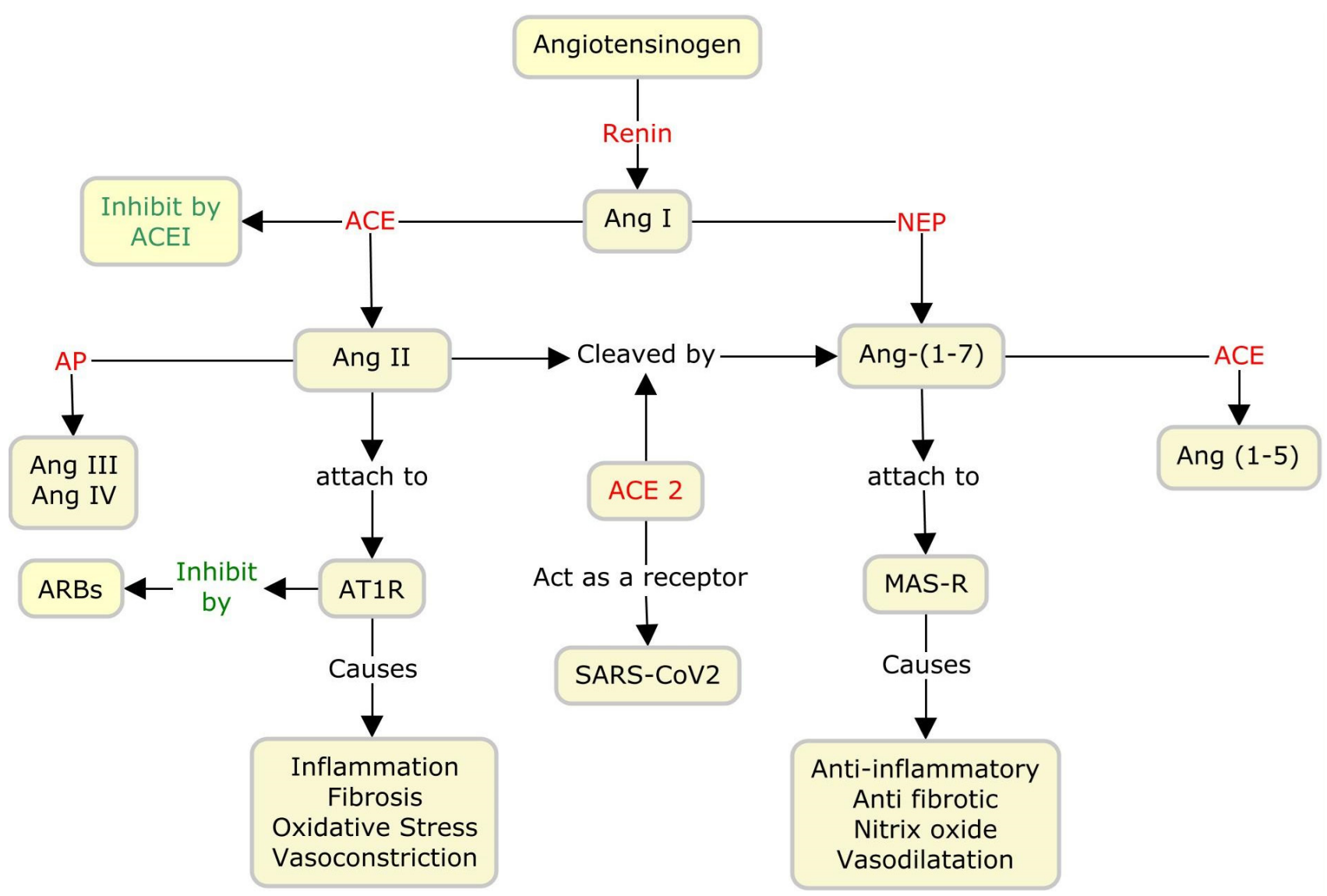

Figure 1. Renin Angiotensin System (RAS)

This figure depicts the RAS system. The words that are highlighted with red color are enzymes responsible for converting corresponding peptides. The words that are highlighted with green color are the inhibitors for enzyme/receptor corresponding to the arrows. Ang; angiotensinogen, ACE; angiotensin-converting enzyme, NEP; neprilysin, AP; activator protein, AT1R; angiotensin II receptor 1, MAS-R; MAS receptor, SARS-CoV2; severe acute respiratory syndrome-coronavirus 2. 
and $\mathrm{ARB}$ can be used to prevent this phenomenon in heart failure. ${ }^{22}$ Furthermore, ACE-I and ARB can prevent the progression of renal failure and can act as an antihypertensive agent by inhibiting angiotensinconverting enzyme and blocking angiotensin receptor, respectively. ${ }^{23,24}$

Diabetes mellitus, hypertension, cardiovascular diseases, and respiratory disease are often found in severe COVID-19 patients. $^{25}$ Based on a pooled analysis, hypertension was independently associated with a nearly 2.5 -fold significantly increased risk of severe and mortality in COVID-19 disease. ${ }^{26}$ In line with hypertension, cardiovascular diseases were also independently associated with approximately 2.5fold significantly increased risk of mortality based on multivariate analysis of prospective cohort study. ${ }^{27}$

This can be explained, in part, by increased susceptibility due to enhanced expression of ACE2, especially those who are taking RAAS blockers and consequently causing local acute respiratory distress syndrome (ARDS) and systemic (multi-organ failure (MOF)/ systemic inflammatory response syndrome (SIRS)) complications. ${ }^{28}$ Meanwhile, others argued that ACE2 expression is already reduced in hypertensive patients and decreases even more when bound to the SARS-CoV-2 virus, tipping the balance off towards Ang II, which contributes to lung injury and cardiovascular disorders. ${ }^{29}$

Although ACE-i or ARB theoretically can cause increased susceptibility to SARS-CoV-2 infection, the cessation of these drugs in patients with cardiovascular disease during a COVID-19 pandemic does not have robust evidence yet. ${ }^{30}$ Discontinuation of ACEi or ARB therapy can worsen cardiac function, thereby increasing the risk of rehospitalization and mortality in patients with heart failure. ${ }^{31}$ Furthermore, abrupt discontinuation of ACE-i or ARB in hypertensive patients can cause spikes in blood pressure and uncontrolled blood pressure rendering the patients an increased risk of sequelae. ${ }^{32,33}$

\section{The Benefit of Continuing ACEi/ARB for Cardio- vascular Indication in COVID - I 9 patients.}

Although human evidence evaluating the safety of ACEi/ARB in the setting of SARS CoV2 infection is still lacking, we can extrapolate from other experimental animal studies, albeit with great caution because findings from basic medical science do not always translate to human physiology.

Angiotensin-converting enzyme 2 (ACE 2) is known to have protective effects on lung physiology. In a mice model of acute lung injury induced by $\mathrm{H} 5 \mathrm{~N} 1$ virus infection and acid aspiration that is deficient from ACE2, increased levels of ACE, angiotensin II, and angiotensin II type 1a receptor (AT1a) induced lung edema and impaired lung function. However, this condition is readily reversed by infusion of human recombinant ACE2 protein. ${ }^{34,35}$ Furthermore, lung injury induced by a respiratory syncytial virus (RSV) in ACE2 deficient mice is reduced by human recombinant ACE2 supplementation and angiotensin II receptor (AT1R) inhibition, in terms of reduced leukocyte cell count, inflammatory reaction, viral titers, and lung edema. ${ }^{36}$ In a model of acute respiratory distress syndrome (ARDS) done in pigs, ACE2 protein significantly improved the respiratory failure outcome by increasing the oxygen levels by almost $40 \% .{ }^{37}$

Losartan, an ARB, when used as a pretreatment for mice model of acute lung injury induced by lipopolysaccharides (LPS) has shown to reduce the inflammatory process in terms of IL- 6 and prevent histological changes such as alveolar wall thickening caused by edema, striking inflammatory cell infiltration, and severe interstitial hemorrhage. Thus, preventing the action of angiotensin II indirectly on pneumocytes by blocking the AT1R by an ARB proved to be protective against acute lung injury. 38

In experimental animal studies, Angiotensin-(1-7), a degradation product of angiotensin II by ACE2, acts through MAS receptor and attenuate the severity of acute lung injury through reduced lung edema, myeloperoxidase activity, histological lung injury score, pulmonary vascular resistance, inflammatory mediator response, lung injury scores, and improved lung function. ${ }^{39-42}$

In another experimental animal study, ACE2 can improve lung function after acute lung injury by antagonizing vascular endothelial growth factor antagonist (VEGFa), a mediator that responsible for increasing permeability of vascular endothelium. ${ }^{43}$ The protective effects of ACE2 are also shown in the model of lung injury induced by H7N9. Whereas of its absence, lung injury is more severe. In addition, AT1 inhibition also attenuates the severity of lung injury. ${ }^{44}$ Moreover, 
ACE2 can prevent pulmonary vascular endothelial apoptosis by inhibiting the angiotensin II cascade, and thus protect the lung from injury. ${ }^{45}$

The Renin angiotensin aldosterone systems (RAAS) are known to play an essential role in the pathogenesis of inflammatory diseases. Blocking the action of angiotensin II by ARBs can prevent its downstream effect of NF-kB transcription factors and activating protein 1 (AP-1) activation. ${ }^{46}$ Furthermore, pro-inflammatory activities orchestrated by multiple cell functions and molecular signalling pathways can be avoided, including progression of lung injury which is already marked in COVID-19 patients. Conversely, Angiotensin (17) mediated by the MAS receptor causes non-proinflammatory effect through the reduction of leukocyte migration and pro-inflammatory cytokines such as TNF- $\alpha$, IFN- $\gamma$, and IL-1 $\beta$ and IL-6. Angiotensin-(1-7) also exerts its anti-inflammatory effect through increasing the anti-inflammatory cytokine, such as IL$10.47-49$

The protective effect was also found in a study of patients with underlying hypertension. A retrospective, multi-center study in China compared the mortality outcome of 1128 adult patients with hypertension diagnosed with COVID-19, including 188 taking RAAS blockers and 940 without using RAAS blockers. They found that inpatient use of ACEI/ARB was unlikely associated with increased mortality risk but was instead associated with a lower risk of all-cause mortality compared with ACEI/ARB non-users. ${ }^{50}$

The three different phases of COVID-19 should be taken into account while we are scrutinizing effects of RAAS blockers in such population. In the first phase, although RAAS blockers can increase ACE2, thereby promoting viral infection, both also prevent Ang II from building-up by increasing ACE2, which metabolizes it to become Ang 1-7. In the second phase, ACE 1 and Ang II are the main culprits, which can be inhibited and blocked by ACE-i and ARB, respectively. ${ }^{21}$ Interestingly, whereas ACE-i/ARB could be detrimental if used in phase three, Ang II is useful in this phase, because it prevents vasodilatation, worsened capillary leak, and impaired endothelial conductance and autoregulation. ${ }^{21}$ Therefore, it is judicious to use RAS blockers in the first two phases. Nevertheless, in phase three, both should be avoided, and Angiotensin II putatively could be utilized for COVID-19 patients who progressed to shock.
In conclusion, angiotensin II is detrimental to lung physiology, but ACE2 and Angiotensin (1-7) counterbalance its effects. ${ }^{51}$ Thus, ACE-I and ARBs have been speculated to be beneficial in COVID-19 patients not just by preventing severe pneumonia but also avoid the negative consequences of cardiovascular diseases. With a caveat that they could be useful in the first two phases of COVID-19 and detrimental for the third phase. In contrast, the contrary is true for Angiotensin II. Nevertheless, further research is needed to investigate the potential therapeutic effect of Angiotensin II.

\section{Latest summary of recommendations from world-wide Societies/Colleges}

Numerous publications related to this issue have been released recently. In general, they are in accordance with continuing ACEi/ARB for patients with distinctive indications, regardless of SARS-CoV2 infection.

\section{Conclusion}

Emerging concerns about RAAS blockers prescription for patients infected by SARS-CoV-2 are based merely on hypothesis-generating data which indicates that ACE2 receptors are critical for viral entry and their levels are upregulated when using these RAAS blockers. Regarding to the scarcity of clinical evidence upon this issue, several world-wide societies have released recommendations to carry on RAAS blockers in patients with obvious cardiovascular indications regardless of COVID-19 status, until later evidences show otherwise. Discontinuing RAAS blockers might cause more harm over benefits, particularly in patients with heart failure in which these agents have been proven to reduce longterm mortality.

\section{Publication Statements}

\section{Publication approval}

All authors read and approved the final manuscript.

\section{Conflict of interest}

None

\section{Sources of funding}




\section{Indonesian Journal of Cardiology}

Table 1. Summaries of recommendation regarding ACEI/ARB for Antihypertensive in Patient with COVID19

\begin{tabular}{|c|c|c|}
\hline Societies/Colleges & Recommendations & Latest Update \\
\hline Indonesian Heart Association ${ }^{52}$ & $\begin{array}{l}\text { Recommends continuing ACEi/ARBS according to standard clinical } \\
\text { practice guidelines due to inconclusive evidence and without adding/ } \\
\text { omitting treatment related to RAAS antagonist }\end{array}$ & March 26, 2020 \\
\hline Australian Diabetes Society ${ }^{53}$ & Recommends that usual antihypertensive therapy is continued & March 29, 2020 \\
\hline $\begin{array}{l}\text { High Blood Pressure Research Council of } \\
\text { Australia }^{54}\end{array}$ & $\begin{array}{l}\text { Recommends that the routine use of ACE-Inhibitors or ARBs should } \\
\text { continue, and patients should not cease blood pressure-lowering } \\
\text { medications unless advised to do so by their physician. }\end{array}$ & March 17, 2020 \\
\hline $\begin{array}{l}\text { American Society of Pediatric } \\
\text { Nephrology }\end{array}$ & $\begin{array}{l}\text { Strongly recommends that patients continue to take their ACE } \\
\text { inhibitors and ARBs, until new evidence to the contrary becomes } \\
\text { available. }\end{array}$ & March 16, 2020 \\
\hline American College of Physicians ${ }^{56}$ & $\begin{array}{l}\text { Encourages continuing ACEis/ARBs because the mortality of patient } \\
\text { confirmed COVID-19 with the cardiovascular disease treated with or } \\
\text { without the use of ACEI/ARB did not show a significant difference in } \\
\text { the outcome, and discontinuing or changing antihypertensive therapy } \\
\text { without medical indication and supervision could lead to adverse } \\
\text { effects and may be harmful }\end{array}$ & March 16, 2020 \\
\hline AHA/HFSA/ACC 57 & $\begin{array}{l}\text { Recommends continuation of ACE-I and ARBs in a patient with } \\
\text { hypertension, heart failure, or ischemic heart disease who are } \\
\text { diagnosed with COVID-19 }\end{array}$ & March 17, 2020 \\
\hline The Renal Association, United Kingdom ${ }^{58}$ & $\begin{array}{l}\text { Supports for continuing ACE-i and ARB in hypertensive patients } \\
\text { because there is no data on the drug will increase the risk of } \\
\text { COVID-19 }\end{array}$ & March 15, 2020 \\
\hline International Society of Hypertension ${ }^{59}$ & $\begin{array}{l}\text { Does not support changing ACEi or ARB in hypertensive patients to } \\
\text { treat or prevent SARS-CoV-2 infection because there is no evidence }\end{array}$ & March 16, 2020 \\
\hline Canada Cardiovascular Society ${ }^{60}$ & $\begin{array}{l}\text { Encourages to continue ACEi, ARB, and ARNI for hypertensive } \\
\text { patients during the COVID-19 pandemic }\end{array}$ & March 20,2020 \\
\hline Hypertension Canada61 & $\begin{array}{l}\text { Endorses patients to continue ACEi/ARBs due to lack of evidence } \\
\text { that patient with hypertension and those treated with ACEi/ARBs are } \\
\text { at higher risk of adverse outcomes from COVID-19 infection }\end{array}$ & March 13, 2020 \\
\hline Spanish Society of Hypertension ${ }^{62}$ & $\begin{array}{l}\text { Treatments with ACEI or ARBs should not be suspended preventively } \\
\text { in stable patients. Otherwise, in a patient with hemodynamic } \\
\text { instability or need for admission due to severity criteria, changes of } \\
\text { treatment should be made on a case-by-case }\end{array}$ & March 16, 2020 \\
\hline $\begin{array}{l}\text { European Renal Association/ European } \\
\text { Dialysis and Transplant Association }{ }^{63}\end{array}$ & $\begin{array}{l}\text { Recommends that patients who are prescribed ACEi/ARB therapy } \\
\text { continue to take these medications at this time unless there is a } \\
\text { compelling, evidence-based indication to discontinue treatment. }\end{array}$ & March 17, 2020 \\
\hline $\begin{array}{l}\text { European Society of Cardiology Council } \\
\text { on Hypertension }{ }^{64}\end{array}$ & $\begin{array}{l}\text { Strongly recommends that physicians and patients should continue } \\
\text { treatment with their usual antihypertensive therapy. More evidence is } \\
\text { needed to support the discontinuing of RAAS blockers. }\end{array}$ & March 13, 2020 \\
\hline European Society of Hypertension ${ }^{65}$ & $\begin{array}{l}\text { Still following the March 13, } 2020 \text { guideline, which is to continue } \\
\text { ACEi/ARBs due to lack of evidence. In those with with severe } \\
\text { symptoms or sepsis, } \\
\text { antihypertensive decisions should be made on a case-by-case basis } \\
\text { taking into account current guidelines }\end{array}$ & March 19, 2020 \\
\hline
\end{tabular}


This paper received no specific grant from any funding agency

\section{Ethical Clearance}

Not Applicable

\section{List Of Abbreviations}

$\begin{array}{lll}\text { COVID-19 } & : \text { coronavirus disease of } 2019 \\ \text { SARS-CoV2 } & : \text { severe acute respiratory syndrome } & \text { coronavirus - } 2 \\ & : \text { angiotensin-converting enzyme } \\ \text { ACE } & : \text { angiotensin receptor blockers } \\ \text { ARBs } & : \text { renin angiotensin aldosterone system } \\ \text { RAAS } & : \text { world health organization } \\ \text { WHO } & : \text { novel coronavirus } \\ \text { nCov } & : \text { angiotensin I } \\ \text { Ang I } & : \text { angiotensin II } \\ \text { Ang II } & : \text { acute respiratory distress syndrome } \\ \text { ARDS } & : \text { multi organ failure } \\ \text { MOF } & : \text { systemic inflammatory response } \\ \text { SIRS } & : \text { syndrome } \\ & \text { angiotensin II receptor type 1a } \\ \text { AT1a } & : \text { receptor } \\ & : \text { lipopolysaccharides } \\ \text { RSV } & : \text { vascular endothelial growth factor } \\ \text { LPS } & \text { antagonist } \\ \text { VEGFa } & \text { activating protein-1 } & \end{array}$

\section{References}

1. WHO | Pneumonia of unknown cause - China. WHO. Accessed April 13, 2020. http://www. who.int/csr/don/05-january-2020-pneumonia-ofunkown-cause-china/en/

2. Lu R, Zhao X, Li J, et al. Genomic characterisation and epidemiology of 2019 novel coronavirus: implications for virus origins and receptor binding. The Lancet. 2020;395(10224):565-574. doi:10.1016/S0140-6736(20)30251-8

3. Coronavirus Disease (COVID-19) - events as they happen. Accessed April 13, 2020. https://www.who. int/emergencies/diseases/novel-coronavirus-2019/ events-as-they-happen

4. COVID-19 Map. Johns Hopkins Coronavirus Resource Center. Accessed April 13, 2020. https:// coronavirus.jhu.edu/map.html

5. Dong E, Du H, Gardner L. An interactive webbased dashboard to track COVID-19 in real time. Lancet Infect Dis. 2020;0(0). doi:10.1016/S14733099(20)30120-1

6. Furuhashi M, Moniwa N, Mita T, et al. Urinary Angiotensin-Converting Enzyme 2 in Hypertensive Patients May Be Increased by Olmesartan, an Angiotensin II Receptor Blocker. Am J Hypertens. 2015;28(1):15-21. doi:10.1093/ajh/hpu086

7. Hoffmann M, Kleine-Weber H, Schroeder S, et al. SARS-CoV-2 Cell Entry Depends on ACE2 and TMPRSS2 and Is Blocked by a Clinically Proven Protease Inhibitor. Cell. 2020;0(0). doi:10.1016/j. cell.2020.02.052

8. von Lueder TG, Krum H. RAAS Inhibitors and Cardiovascular Protection in Large Scale Trials. Cardiovasc Drugs Ther. 2013;27(2):171-179. doi:10.1007/s10557-012-6424-y

9. Ma TK, Kam KK, Yan BP, Lam Y-Y. Reninangiotensin-aldosterone system blockade for cardiovascular diseases: current status. $\mathrm{Br} J$ Pharmacol. 2010;160(6):1273-1292. doi:10.1111/ j.1476-5381.2010.00750.x

10. Cascella M, Rajnik M, Cuomo A, Dulebohn SC, Di Napoli R. Features, Evaluation and Treatment Coronavirus (COVID-19). In: StatPearls. StatPearls Publishing; 2020. Accessed April 13, 2020. http:// www.ncbi.nlm.nih.gov/books/NBK554776/

11. SARS-CoV-2 Cell Entry Depends on ACE2 and TMPRSS2 and Is Blocked by a Clinically Proven Protease Inhibitor. Accessed April 15, 2020. https://www.ncbi.nlm.nih.gov/pmc/articles/ PMC7102627/

12. Danser AHJ, Epstein M, Batlle D. ReninAngiotensin System Blockers and the COVID-19 Pandemic: At Present There Is No Evidence to Abandon Renin-Angiotensin System Blockers. Hypertension. Published online March 25, 2020. doi:10.1161/HYPERTENSIONAHA. 120.15082

13. Vaduganathan M, Vardeny O, Michel T, McMurray JJV, Pfeffer MA, Solomon SD. Renin-AngiotensinAldosterone System Inhibitors in Patients with COVID-19. N Engl J Med. Published online March 30, 2020:NEJMsr2005760. doi:10.1056/ NEJMsr2005760

14. Tikellis C, Thomas MC. Angiotensin-Converting 
Enzyme 2 (ACE2) Is a Key Modulator of the Renin Angiotensin System in Health and Disease. Int J Pept. 2012;2012:1-8. doi:10.1155/2012/256294

15. Fountain JH, Lappin SL. Physiology, Renin Angiotensin System. In: StatPearls. StatPearls Publishing; 2020. Accessed April 14, 2020. http:// www.ncbi.nlm.nih.gov/books/NBK470410/

16. Santos Robson Augusto. Angiotensin-(1-7). Hypertension. 2014;63(6):1138-1147. doi:10.1161/HYPERTENSIONAHA.113.01274

17. Chen L, Hao G. The role of angiotensin-converting enzyme 2 in coronaviruses/influenza viruses and cardiovascular disease. :5.

18. Touyz RM, Li H, Delles C. ACE2 the Janusfaced protein - from cardiovascular protection to severe acute respiratory syndrome-coronavirus and COVID-19. Clin Sci. 2020;134(7):747-750. doi: $10.1042 / C S 20200363$

19. Kuba K, Imai Y, Rao S, et al. A crucial role of angiotensin converting enzyme 2 (ACE2) in SARS coronavirus-induced lung injury. Nat Med. 2005;11(8):875-879. doi:10.1038/nm1267

20. Tseng C-TK, Huang C, Newman P, et al. Severe Acute Respiratory Syndrome Coronavirus Infection of Mice Transgenic for the Human AngiotensinConverting Enzyme 2 Virus Receptor. J Virol. 2007;81(3):1162-1173. doi:10.1128/JVI.0170206

21. Leisman DE, Deutschman CS, Legrand M. Facing COVID-19 in the ICU: vascular dysfunction, thrombosis, and dysregulated inflammation. Intensive Care Med. Published online April 28, 2020. doi:10.1007/s00134-020-06059-6

22. Anavekar NS, Solomon SD. Angiotensin II receptor blockade and ventricular remodelling. J Renin Angiotensin Aldosterone Syst. 2005;6(1):43-48. doi:10.3317/jraas.2005.006

23. Hao G, Wang Z, Guo R, et al. Effects of ACEI/ $A R B$ in hypertensive patients with type 2 diabetes mellitus: a meta-analysis of randomized controlled studies. BMC Cardiovasc Disord. 2014;14(1):148. doi:10.1186/1471-2261-14-148

24. Ponikowski P, Voors AA, Anker SD, et al. 2016 ESC Guidelines for the diagnosis and treatment of acute and chronic heart failureThe Task Force for the diagnosis and treatment of acute and chronic heart failure of the European Society of Cardiology
(ESC)Developed with the special contribution of the Heart Failure Association (HFA) of the ESC. Eur Heart J. 2016;37(27):2129-2200. doi:10.1093/ eurheartj/ehw128

25. Yang J, Zheng Y, Gou X, et al. Prevalence of comorbidities in the novel Wuhan coronavirus (COVID-19) infection: a systematic review and meta-analysis. Int J Infect Dis. 2020;0(0). doi:10.1016/j.ijid.2020.03.017

26. Lippi G, Wong J, Henry BM. Hypertension and its severity or mortality in Coronavirus Disease 2019 (COVID-19): a pooled analysis. Pol Arch Intern Med. Published online March 31, 2020. doi:10.20452/pamw. 15272

27. Du R-H, Liang L-R, Yang C-Q, et al. Predictors of Mortality for Patients with COVID-19 Pneumonia Caused by SARS-CoV-2: A Prospective Cohort Study. Eur Respir J. Published online January 1, 2020. doi:10.1183/13993003.00524-2020

28. Kuster GM, Pfister O, Burkard T, et al. SARSCoV2: should inhibitors of the renin-angiotensin system be withdrawn in patients with COVID-19? Eur Heart J. doi:10.1093/eurheartj/ehaa235

29. Guan W, Ni Z, Hu Y, et al. Clinical Characteristics of Coronavirus Disease 2019 in China. N Engl J Med. 2020;0(0):null. doi:10.1056/NEJMoa2002032

30. Guo Junyi, Huang Zheng, Lin Li, Lv Jiagao. Coronavirus Disease 2019 (COVID-19) and Cardiovascular Disease: A Viewpoint on the Potential Influence of Angiotensin-Converting Enzyme Inhibitors/Angiotensin Receptor Blockers on Onset and Severity of Severe Acute Respiratory Syndrome Coronavirus 2 Infection. J Am Heart Assoc. 2020;9(7):e016219. doi:10.1161/ JAHA.120.016219

31. Gilstrap Lauren G., Fonarow Gregg C., Desai Akshay S., et al. Initiation, Continuation, or Withdrawal of Angiotensin-Converting Enzyme Inhibitors/ Angiotensin Receptor Blockers and Outcomes in Patients Hospitalized With Heart Failure With Reduced Ejection Fraction. J Am Heart Assoc. 6(2):e004675. doi:10.1161/JAHA.116.004675

32. Piccoli GB, Anania P, Biancone L, et al. Hypertensive rebound after angiotensin converting enzyme inhibitor withdrawal in diabetic patients with chronic renal failure. Nephrol Dial Transplant. 2001;16(5):1084-1085. doi:10.1093/ 
ndt/16.5.1084

33. Mudumbai SC, Takemoto S, Cason BA, Au S, Upadhyay A, Wallace AW. Thirty-day mortality risk associated with the postoperative nonresumption of angiotensin-converting enzyme inhibitors: A retrospective study of the veterans affairs healthcare system. J Hosp Med. 2014;9(5):289-296. doi:10.1002/jhm.2182

34. Imai Y, Kuba K, Rao S, et al. Angiotensin-converting enzyme 2 protects from severe acute lung failure. Nature. 2005;436(7047):112-116. doi:10.1038/ nature 03712

35. Angiotensin-converting enzyme 2 protects from lethal avian influenza A H5N1 infections | Nature Communications. Accessed April 13, 2020. https:// www.nature.com/articles/ncomms 4594

36. Gu H, Xie Z, Li T, et al. Angiotensin-converting enzyme 2 inhibits lung injury induced by respiratory syncytial virus. Sci Rep. 2016;6:19840. doi:10.1038/srep19840

37. Treml B, Neu N, Kleinsasser A, et al. Recombinant angiotensin-converting enzyme 2 improves pulmonary blood flow and oxygenation in lipopolysaccharide-induced lung injury in piglets. Crit Care Med. 2010;38(2):596-601. doi:10.1097/ CCM.0b013e3181c03009

38. Liu J, Zhang P-S, Yu Q, et al. Losartan inhibits conventional dendritic cell maturation and Th1 and Th17 polarization responses: Novel mechanisms of preventive effects on lipopolysaccharide-induced acute lung injury. Int J Mol Med. 2012;29(2):269276. doi: $10.3892 /$ ijmm. 2011.818

39. Asperen RMW, Lutter R, Specht PA, et al. Acute respiratory distress syndrome leads to reduced ratio of ACE/ACE2 activities and is prevented by angiotensin-(1-7) or an angiotensin II receptor antagonist. J Pathol. 2011;225(4):618-627. doi:10.1002/path.2987

40. Klein N, Gembardt F, Supé S, et al. Angiotensin-(1-7) Protects From Experimental Acute Lung Injury. Crit Care Med. 2013;41(11). doi:10.1097/CCM.0b013e31828a6688

41. Wagenaar GTM, Laghmani EH, Fidder $M$, et al. Agonists of MAS oncogene and angiotensin II type 2 receptors attenuate cardiopulmonary disease in rats with neonatal hyperoxia-induced lung injury. Am J Physiol-Lung Cell Mol
Physiol. 2013;305(5):L341-L351. doi:10.1152/ ajplung.00360.2012

42. Zambelli V, Bellani G, Borsa R, et al. Angiotensin-(1-7) improves oxygenation, while reducing cellular infiltrate and fibrosis in experimental Acute Respiratory Distress Syndrome. Intensive Care Med Exp. 2015;3(1):8. doi:10.1186/ s40635-015-0044-3

43. Yu X, Lin Q, Qin X, et al. ACE2 Antagonizes VEGFa to Reduce Vascular Permeability During Acute Lung Injury. Cell Physiol Biochem Int J Exp Cell Physiol Biochem Pharmacol. 2016;38(3):10551062. doi:10.1159/000443056

44. Yang P, Gu H, Zhao Z, et al. Angiotensin-converting enzyme 2 (ACE2) mediates influenza H7N9 virusinduced acute lung injury. Sci Rep. 2014;4:7027. doi: $10.1038 /$ srep07027

45. Ji Y, Gao F, Sun B, Hao J, Liu Z. AngiotensinConverting Enzyme 2 Inhibits Apoptosis of Pulmonary Endothelial Cells During Acute Lung Injury Through Suppressing SMAD2 Phosphorylation. Cell Physiol Biochem Int J Exp Cell Physiol Biochem Pharmacol. 2015;35(6):22032212. doi:10.1159/000374025

46. Unthank JL, McClintick JN, Labarrere CA, Li L, Distasi MR, Miller SJ. Molecular basis for impaired collateral artery growth in the spontaneously hypertensive rat: insight from microarray analysis. Physiol Rep. 2013;1(2):e0005. doi:10.1002/phy2.5

47. Simóes E Silva AC, Teixeira MM. ACE inhibition, ACE2 and angiotensin-(1-7) axis in kidney and cardiac inflammation and fibrosis. Pharmacol Res. 2016;107:154-162. doi:10.1016/j. phrs.2016.03.018

48. Simões e Silva AC, Silveira KD, Ferreira AJ, Teixeira MM. ACE2, angiotensin-(1-7) and Mas receptor axis in inflammation and fibrosis. Br J Pharmacol. 2013;169(3):477-492. doi:10.1111/bph.12159

49. Wang X, Khaidakov M, Ding Z, et al. Cross-talk between inflammation and angiotensin II: studies based on direct transfection of cardiomyocytes with AT1R and AT2R cDNA. Exp Biol Med Maywood NJ. 2012;237(12):1394-1401. doi:10.1258/ ebm.2012.012212

50. Zhang P, Zhu L, Cai J, et al. Association of Inpatient Use of Angiotensin Converting Enzyme Inhibitors and Angiotensin II Receptor Blockers 
with Mortality Among Patients With Hypertension Hospitalized With COVID-19. Circ Res. Published online April 17, 2020:CIRCRESAHA.120.317134. doi:10.1161/CIRCRESAHA.120.317134

51. Ferrario Carlos M., Jessup Jewell, Chappell Mark C., et al. Effect of Angiotensin-Converting Enzyme Inhibition and Angiotensin II Receptor Blockers on Cardiac Angiotensin-Converting Enzyme 2. Circulation. 2005;111(20):2605-2610. doi:10.1161/CIRCULATIONAHA.104.510461

52. REKOMENDASI RAAS ANTAGONIS PADA COVID-19 - News \& Event | Perhimpunan Dokter Spesialis Kardiovaskuler Indonesia (PERKI). Accessed April 13, 2020. http://www.inaheart.org/ news_and_events/news/2020/3/26/rekomendasi_ raas_antagonis_pada_COVID-19

53. Ross G. Australian Diabetes Society Communique for Diabetes Health Professionals regarding COVID-19 pandemic [Internet]. [cited $2020 \mathrm{Apr}$ 19]. Available from: https://diabetessociety.com. au/downloads/20200329\%20ADS\%20Letter\%20 re $\% 20$ COVID-19\%20 and $\% 20$ Diabetes $\% 20$ HPs\%2029032020_Update\%20.pdf

54. Secretariat Y. Statement on COVID-19 and Blood Pressure Medication. HBPRCA | High Blood Pressure Research Council of Australia. Published March 17, 2020. Accessed April 19, 2020. https:// www.hbprca.com.au/statement-on-COVID-19/

55. COVID-19 Information - American Society of Pediatric Nephrology (ASPN). Accessed April 19, 2020. https://www.aspneph.org/COVID-19information/

56. COVID-19: An ACP Physician's Guide + Resources (Last Updated April 17, 2020 at 4 PM) - Treatment: Pharmacotherapy. Accessed April 19, 2020. https://assets. acponline.org/coronavirus/scormcontent/? \& $\mathrm{ga}=2.24115962 .1176416039 .1587301912$ 1499942903.1587301912 \#/ lessons/ Mq10jIISmbXLiv0N6vF-nByg_ATABT_p

57. HFSA/ACC/AHA Statement Addresses Concerns Re: Using RAAS Antagonists in COVID-19. American College of Cardiology. Accessed April 19, 2020. http\%3a\%2f\%2fwww.acc.org\%2flatestin-cardiology $\% 2$ farticles $\% 2 f 2020 \% 2 f 03 \% 2 f 17 \%$ $2 \mathrm{f} 08 \% 2 \mathrm{f} 59 \% 2 \mathrm{fhfsa}$-acc-aha-statement-addressesconcerns-re-using-raas-antagonists-in-COVID-19
58. The Renal Association, UK position statement on COVID-19 and ACE Inhibitor/Angiotensin Receptor Blocker use - The Renal Association. Accessed April 19, 2020. https://renal.org/ COVID-19/ra-resources-renal-professionals/renalassociation-uk-position-statement-COVID-19-aceinhibitorangiotensin-receptor-blocker-use/

59. A statement from the International Society of Hypertension on COVID-19 | The International Society of Hypertension. Accessed April 19, 2020. https://ish-world.com/news/a/A-statement-fromthe-International-Society-of-Hypertension-onCOVID-19/

60. Krahn A. GUIDANCE FROM THE CCS COVID-19 RAPID RESPONSE TEAM [Internet]. [cited 2020 Apr 19]. Available from: http://www. ccs.ca/images/Images_2020/CCS_CHFS_Update_ COVID_CV_medications_Mar20.pdf

61. Khan N. Hypertension Canada's Statement on: Hypertension, ACE-Inhibitors and Angiotensin Receptor Blockers and COVID-19. Published March 13, 2020. Accessed April 15, $2020 . \quad$ https://hypertension.ca/wp-content/ uploads/2020/03/2020-30-15-HypertensionCanada-Statement-on-COVID-19-ACEi-ARB.pdf

62. COVID-19: Comunicado Urgente | Manejo de pacientes hipertensos |. Seh-lelha - Sociedad Española de Hipertensión Liga Española para la Lucha contra la Hipertensión Arterial. Published March 16, 2020. Accessed April 19, 2020. https:// www.seh-lelha.org/COVID-19/

63. Cohen J. NephJC statement on SARS-CoV-2 virus, COVID-19, and ACEi/ARB treatment. :4.

64. Position Statement of the ESC Council on Hypertension on ACE-Inhibitors and Angiotensin Receptor Blockers. Accessed April 19, 2020. https://www.escardio.org/Councils/Council-onHypertension-(CHT)/News/position-statementof-the-esc-council-on-hypertension-on-aceinhibitors-and-ang, https://www.escardio.org/ Councils/Council-on-Hypertension-(CHT)/ News/position-statement-of-the-esc-council-onhypertension-on-ace-inhibitors-and-ang

65. ESH LETTER COVID-19 | European Society of Hypertension. Accessed April 19, 2020. https://www.eshonline.org/spotlights/esh-letterCOVID-19-2/ 